\title{
Analysis the satisfaction hierarchy structure of e-commerce logistics professional student in College Based on SPSS
}

\author{
Xumei ZHANG ${ }^{1, *}$, Shaohua WEI ${ }^{2}$ \\ ${ }^{1}$ Wuhan University of Science and Technology, Wuhan, China \\ ${ }^{2}$ Xi'an Technological University North Institute of Information Engineering, Xi'an, China \\ zxm037600@163.com
}

\begin{abstract}
Through literature review, this article summarizes several existing measurement systems of university student satisfaction, combined with the e-commerce and logistics 's characteristics, extracts 16 measures which can reflect the characteristics of the satisfaction of e-commerce logistics student. After the completion of the initial scale of establishment and focus group interviews, these measures is designed and handed out questionnaires, then the questionnaire data collection is completed and the results of the questionnaire data are entered into the statistical software of SPSS19.0 to do the principal component analysis of factor analysis, and lastly establish the satisfaction hierarchy structure of e-commerce logistics professional student in College.
\end{abstract}

Keywords: e-commerce logistics, Satisfaction, Factor analysis, SPSS

\section{Introduction}

In recent years, with the rapid development of e-commerce, the traditional companies transform and upgrade with e-commerce. Then society needs a large number of professional talents of e-commerce logistics. Therefore, universities set up e-commerce logistics profession year by year, and vigorously develop e-commerce logistics professionals. In the face of the rapid development of specialty construction, however, the analysis of the satisfaction degree of college students which are the customers of universities is must.

At present, the typical country abroad for college students' degree of satisfaction analysis is the United States, where the survey is since 1994, and the college students' satisfaction scale is designed by Laurie and Stephanie, which is of 12 indexes. In china the college students' degree of satisfaction analysis is from the beginning of the 21 st century. the representative studies on quantitative in college students' satisfaction measurement are: Jun-xue liu (2006) evaluate the college students' degree of satisfaction from 15 indexes which are teaching plan, teaching organization and management system, management responsibility, discipline knowledge, teacher professional ethics and teacher's teaching, teaching facilities, campus environment, cultural atmosphere, the staff service consciousness, teaching material, the degree of knowledge, practical progress and logistics service. Ya-ping Chang (2007) found that school environment and atmosphere, student management mechanism, teaching infrastructure, logistics service, extra-curricular activities, professional quality of teachers, curriculum management, staff service consciousness and personal development are the important indicators which affect college students' satisfaction. Xi-zhou Tian (2007) points out that the college students' satisfaction is formed by six factors which are teacher's teaching, teaching management, student work, school environment, teaching conditions and social reputation. Zhou-ling Xing (2009) points out that the students' satisfaction is composed of five dimensions, namely, the teaching effect, curriculum management, student management mechanism, the concern for the individual, campus environment, and social reputation. Xiao-hui Xu (2010) points out that the factors that affect college students' satisfaction are the school image, professional construction, teachers and teaching, the humanities environment, live in the dormitory administrator, restaurant service, library and network resources and natural environment. But look up from the current literature and the perspective of e-commerce professional papers for college students' degree of satisfaction analysis is found, therefore, this article will take the students of electronic commerce and logistics professional at 
Wuhan university of science and technology as the object, analysis the degree of satisfaction of professional college students..

\section{The Study Design}

\subsection{The preparation of the initial scale}

According to the current research on university student satisfaction, based on the university student satisfaction evaluation items of Jun-xue liu, And compared with the other university student satisfaction evaluation index system, extracts 16 attribute words which has general representative e-commerce logistics student satisfaction. The initial attribute words of e-commerce logistics student satisfaction are shown in table 1.

Table 1. initial attribute words of e-commerce logistics student satisfaction $(n=16)$

\begin{tabular}{c|c|c|c}
\hline $\begin{array}{c}\text { campus environment } \\
\text { knowledge }\end{array}$ & social reputation & network resources & teaching plan \\
\hline $\begin{array}{c}\text { Teacher professional } \\
\text { ethics }\end{array}$ & teacher's teaching & $\begin{array}{c}\text { practical progress and } \\
\text { logistics service }\end{array}$ & personal development \\
\hline management system & management responsibility & $\begin{array}{c}\text { the staff service } \\
\text { conscious }\end{array}$ & logistics service \\
\hline
\end{tabular}

\subsection{The questionnaire design and investigation}

Before the design of questionnaire, the author conducted focus group interviews firstly which is formed by students of e-commerce and logistics professional in Wuhan university of science and technology and relevant experts. After focus group interviews, researchers can use short time to collect so many features and information about the object of study, which is a great help to the research. Focus group interviews not only play an important role on the prepared for the initial scale and measure to the extraction of item factors, but also own the advantages of economical and practical and to save time. Through the focus group interview results, there is no objection to the attribute words of table 1 .

In accordance with the relevant research literature, the author consults the opinions of relevant experts and designs questionnaire on the basis, replaces the student satisfaction attribute words with more specific and clear questions. Questionnaire adopts 5 Richter scale, with $1 \sim 5$ represents "very dissatisfied" to "very satisfied". When the design of the questionnaire is finished, the author invited 16 students who often focus on the development of e-commerce and logistics professional, consulted their opinions and suggestions to the problems of the questionnaire, they said the questionnaire questions express clearly, won't produce misunderstanding, and could be a lot of questionnaire survey.

After the final questionnaire, this article adopts the way of issuing paper questionnaires to collect data. In order to ensure the quality of the data collection the following measures are taken: (1) to avoid repetition answer, each of the respondents only issues a questionnaire,; (2) the questionnaire is designed in a page, and the problem on the premise is clearly designed to the shortest, avoids the respondents to lose patience, and fill out the situation; (3) by means of artificial to screen the questionnaire where six consecutive choose the same answer. These measures can ensure respondents truthfully fill out the questionnaire. 173 valid questionnaires were received for the survey.

\section{The Results of Analysis}

\section{1 exploratory factor analysis}

In this article, the related measures of electronic commerce and logistics student satisfaction are 16 originally. And the purpose of factor analysis is to find out less meaningful factors which reflect the satisfaction of the basic structure, and also can keep the original data structure. Measure sample number of exploratory factor analysis is at least five times, ideally more than 10 times. So when the number is 16, this article explores the measure of a sample number is 173 , the number of samples is more than measure number 10 times, so the collected sample data is valid. 


\subsection{KMO and Bartlett's test}

After the factor analysis of 16 measure items, KMO measure and Bartlett's test results are shown in table 2.In this paper, the Bartlett 's inspection probability of a value of 0.000 , significance level is 0.05 , the probability value is less than the significance level, Bartlett 's inspection results are significant, suitable for factor analysis. KMO value equals to 0.814 , which is also suitable for factor analysis.

Table 2. KMO measure and Bartlett's test

\begin{tabular}{c|c|c}
\hline \multicolumn{2}{c|}{ Sampling enough degrees of KMO measurements } & .814 \\
\hline Bartlett's spherical test & approximate chi-square & 650.357 \\
\cline { 2 - 3 } & df & 120 \\
\cline { 2 - 3 } & Sig. & .000 \\
\hline
\end{tabular}

\subsection{Factor analysis based on SPSS}

When choosing factor spinning method, this article uses the method of maximum variance to observe measure of load value. Hair have proposed that it can be considered to be significant when the load value measure is greater than 0.30 , and it is more important when the load value measure is greater than 0.40 , more than 0.50 is very significant. So in this article the standard measure of load value is of 0.50 , and extraction factor of eigenvalues is greater than 1. Using SPSS19.0 software tools with principal component analysis (PCA), after the equation to maximize orthogonal rotation, four factors are extracted, and the factor characteristic value is more than 1, the explained overall variance is $52.483 \%$ (see table 3 ). The main purpose of orthogonal rotation is rearranging the measure in each factor of load value, and form the rotating factor matrix. Table 4 is the rotating component matrix which is determined by measure load value based on the rotation of maximum variance method.

Table 3. explained overall variance

\begin{tabular}{c|c|c|c|c|c|c|c|c|c}
\hline component & \multicolumn{3}{|l|}{ initial eigenvalue } & \multicolumn{3}{l|}{$\begin{array}{l}\text { extraction of sum of squares to } \\
\text { load }\end{array}$} & \multicolumn{2}{l|}{ rotating square loaded } \\
\cline { 2 - 11 } & Total & $\begin{array}{c}\text { Variance } \\
\%\end{array}$ & $\begin{array}{c}\text { Cumulative } \\
\%\end{array}$ & Total & $\begin{array}{c}\text { Variance } \\
\%\end{array}$ & $\begin{array}{c}\text { Cumulative } \\
\%\end{array}$ & Total & $\begin{array}{c}\text { Variance } \\
\%\end{array}$ & $\begin{array}{c}\text { Cumulative } \\
\%\end{array}$ \\
\hline 1 & 4.585 & 28.654 & 28.654 & 4.585 & 28.654 & 28.654 & 2.592 & 16.202 & 4.585 \\
\hline 2 & 1.441 & 9.008 & 37.662 & 1.441 & 9.008 & 37.662 & 2.376 & 14.847 & 1.441 \\
\hline 3 & 1.227 & 7.668 & 45.330 & 1.227 & 7.668 & 45.330 & 1.794 & 11.212 & 1.227 \\
\hline 4 & 1.144 & 7.153 & 52.483 & 1.144 & 7.153 & 52.483 & 1.635 & 10.222 & 1.144 \\
\hline 5 & .958 & 5.988 & 58.471 & & & & & & \\
\hline 6 & .953 & 5.954 & 64.425 & & & & & & \\
\hline 7 & .882 & 5.511 & 69.937 & & & & & & \\
\hline 8 & .754 & 4.715 & 74.651 & & & & & & \\
\hline 9 & .666 & 4.165 & 78.816 & & & & & & \\
\hline 10 & .648 & 4.049 & 82.865 & & & & & & \\
\hline 11 & .592 & 3.702 & 86.567 & & & & & & \\
\hline 12 & .553 & 3.459 & 90.025 & & & & & & \\
\hline 13 & .449 & 2.808 & 92.833 & & & & & & \\
\hline 14 & .421 & 2.634 & 95.467 & & & & & & \\
\hline 15 & .378 & 2.366 & 97.833 & & & & & & \\
\hline 16 & .347 & 2.167 & 100.000 & & & & & & \\
\hline
\end{tabular}


Table 4. rotating component matrix component

\begin{tabular}{c|c|c|c|c}
\hline & \multicolumn{4}{|c}{ component } \\
\cline { 2 - 5 } & 1 & 2 & 3 & 4 \\
\hline campus environment & .120 & .262 & -.008 & .810 \\
\hline social reputation & .149 & .031 & .253 & .808 \\
\hline network resources & .131 & .489 & .161 & .308 \\
\hline teaching plan & .587 & .265 & -.208 & .118 \\
\hline the degree of knowledge & .032 & .452 & .724 & .005 \\
\hline teaching organization & .616 & .155 & .172 & -.062 \\
\hline practical progress and logistics service & .364 & .094 & .520 & .130 \\
\hline personal development & .057 & .020 & .679 & .127 \\
\hline teacher professional ethics & .523 & -.161 & .406 & .121 \\
\hline teacher's teaching & .666 & .169 & .155 & .194 \\
\hline teaching facilities & .645 & .075 & .300 & .243 \\
\hline teaching material & .576 & .291 & -.009 & .040 \\
\hline management system & .016 & .674 & .027 & .106 \\
\hline management responsibility & .233 & .593 & .082 & .232 \\
\hline the staff service conscious & .227 & .741 & .012 & -.051 \\
\hline
\end{tabular}

In order to describe the relationship between factors, factor in load matrix is rotated. The standard to eliminate factor is that all factors which on the load quantity is less than 0.5 the index has been dropped, and when factor loading quantity in the two factors is greater than 0.5 the index has been dropped, so that every index in the only the rotation of the main factors on the load quantity is greater than 0.5. According to this standard, this article has one factor to be eliminated.

\section{4 factor structure analysis and naming}

Principal component factor analysis was carried out on the item 16 measure, formed the four factors, as shown in table 5. Looked from the factor matrix, the item 16 measure factors respectively represent four parts about the satisfaction of university students for the e-business logistics professional, such as management service level, personal satisfaction level, level of satisfaction of teaching ,and satisfaction level of perception and environment. According to the analysis of the principal component factor, this paper builds evaluation index system of students' satisfaction in e-commerce logistics (table 5).

Table 5. evaluation index system of students' satisfaction in e-commerce logistics

\begin{tabular}{|c|c|c|}
\hline First level index & Second level index & Third level index \\
\hline \multirow{15}{*}{$\begin{array}{l}\text { students' satisfaction in } \\
\text { e-commerce logistics }\end{array}$} & \multirow[t]{4}{*}{ management service level } & management system \\
\hline & & management responsibility \\
\hline & & the staff service conscious \\
\hline & & logistics service \\
\hline & \multirow[t]{3}{*}{ personal satisfaction level } & the degree of knowledge \\
\hline & & $\begin{array}{l}\text { practical progress and logistics } \\
\text { service }\end{array}$ \\
\hline & & Personal development \\
\hline & \multirow[t]{6}{*}{ level of satisfaction of teaching } & teaching plan \\
\hline & & teaching organization \\
\hline & & teacher professional ethics \\
\hline & & teacher's teaching \\
\hline & & teaching facilities \\
\hline & & teaching material \\
\hline & \multirow{2}{*}{$\begin{array}{l}\text { satisfaction level of perception } \\
\text { and environment }\end{array}$} & campus environment \\
\hline & & social reputation \\
\hline
\end{tabular}

\section{Conclusions}

Through literature review, this article summarizes several existing measurement systems of university student satisfaction, combined with the e-commerce and logistics 's characteristics, extracts 16 measures which can reflect the characteristics of the satisfaction of e-commerce logistics 
student. After the completion of the initial scale of establishment and focus group interviews, these measures is designed and handed out questionnaires, then the questionnaire data collection is completed and the results of the questionnaire data are entered into the statistical software of SPSS19.0 to do the principal component analysis of factor analysis, and lastly establish the satisfaction hierarchy structure of e-commerce logistics professional student in College which is contributed to the construction and development of e-commerce logistics profession.

\section{Acknowledgement}

We gratefully acknowledge the excellent comments made by the reviewers. This study is supported by logistics teaching reform and research subject of China Society of Technology under Grant No. JZW2015046 and Natural Science Foundation of China (NSFC) under Grant No. 51275365 and school fund of Wuhan University of Science and Technology under Grant No.250089 and open fund of Wuhan University of Science and Technology under Grant No.C1009 Hubei Province Collaborative Innovation Center for Automotive Part and Assembly Technology.

\section{References}

[1] LA Schreiner. The Contribution of Student Satisfaction to Persistence[J]. Journal of College Student Retention Research Theory \& Practice, 2013, 15(1):73-111.

[2] Jun-xue liu. Factors that affect college students studying degree of satisfaction and its degree of empirical study [J]. Journal of higher education research ， 2006（11）: 91-97.

[3] Ya-ping Chang. China's college students student satisfaction evaluation system and evaluation model of research [J]. Journal of higher education research, 2007 (9) : 82-87.

[4] Xi-zhou Tian. College student satisfaction survey and analysis [J]]. Higher education to explore, 2007 (5) : 126-128.

[5] Zhou-ling Xing. Editing and verification of college students' satisfaction scale [J]. Journal of heilongjiang province higher education research, 2009 (4) : 21-24.

[6] Xiao-hui Xu. University students satisfaction assessment scale to build [J]. Journal of higher education development and evaluation, 2010(6): 55-58.

[7] Howard, AJohn, JNSheth. The Theory of Buyer Behavior[M]. New York: John Wiley and Sons, 1969. 21 27.

[8] RLOliver. Satisfaction: A Behavioral Perspective on the Consumer[M]. New York: The McGraw-Hill Companies, Inc. 1997. 1 10.Bird R B, Stewart W E. (1960).Lightfoot E N. Transport Phenomena. New York: John Wiley \& Sons Inc, 75

[9] Eugene W. Anderson, Claes Fornell, Donald R. Lehmann . Customer satisfaction, Market Share, and Profitability: Findings From Sweden [J]. Journal of Marketing, 1994, 58 (3): 53 66.

[10] Claes Fornell, Michael D. Johnson, Eugene W. Anderson, Jaesung Cha, Barbara Everitt Bryant. The American Customer Satisfaction Index: Nature, purpose, and findings [J] . Journal of Marketing, 1996, 60 (4): 7 18.

[11] Joreskog, Karl G. Ageneral approach to confirmatory maximum factor analysis. Psychometrika, 1969, 34.

[12] Anderson J C,Gerbin D W. Structural equation modeling in practice: A review and recommended two-step approach. Psychological Bulletin,1998,103:411-423.

[13] Wail Malaty, Pathman D E. Factors Affecting the Match Rate of Rural Training Tracks in Family Practice. Family Medicine, 2002,4:258-262.

[14] Bentler P M. Multivariate analysis with latent variables: causal modeling. Annual Review of Psychology, 1980, 31:419-456.

[15] Wail Malaty. Pathman DE. Factors Affecting the Match Rate of Rural Training Tracks in Family Practice. Family Medicine, 2002,4:258-262. 